\title{
Assessment of coal dust particles influence on marine mollusk Modiolus modiolus
}

\author{
K.Y. Kirichenko, K.S. Pikula, V.V. Chaika, A.M. Zakharenko, A.S. Kholodov, \\ V.V. Chernyshev, M.O. Tretyakova \& K.S. Golokhvast \\ Far Eastern Federal University, Vladivostok, Russian Federation
}

\author{
A.S. Kholodov \\ Far East Geological Institute Far Eastern Branch RAS, Vladivostok, Russian Federation
}

K.S. Golokhvast

N.I. Vavilov All-Russian Institute of Plant Genetic Resources, Saint-Petersburg, Russian Federation

\begin{abstract}
Among the multiple anthropogenic factors, air pollution is associated with the influence of pedosphere and its components on humans and environment. The disturbance of natural balance is facilitated by large-scale development of mineral deposits and associated environmental pollution by harmful components. The increasing anthropogenic impact require scientific and technical examination, introduction of air pollution monitoring systems, amendments to state regulatory acts, and practical solutions to the problems of mineral resources management. This study deals with the ecotoxicological assessment of the influence of coal dust microparticles on a typical representative of marine biota, namely mollusk Modiolus modiolus. We did not detect acute toxicological hazard of coal dust particles to the representatives of marine biota, however, the observed changes in the state of hemocytes of mollusk M. modiolus suggest that there is a chronic exposure.
\end{abstract}

\section{INTRODUCTION}

The port complex of Nakhodka city is located in thse southwestern part of Primorsky Krai on the shores of Nakhodka Bay and Vostok Bay, Sea of Japan. This port complex ranks first in the Russian Far East and second in Russia in terms of cargo turnover (Naumov, 2016). There is a steady dynamic in cargo turnover, from 59.6 million tons in 2012 to 80 million tons in 2015. Vostochny Port, the largest in the Far East, demonstrates annual growth in coal transshipment volumes (http://www.vostport.ru/company/statistics). Continuously growing volumes of coal transshipment (tens of millions of tons) through the port infrastructure of the Nakhodka city district, which is not designed for these purposes (no sanitary protection zones or dust suppression systems), have led to the increased emissions of coal dust into the atmosphere and degradation of the environment in the region.

The state of ambient air is one of the most significant environmental factors affecting the health of people in urban areas (Lelieveld et al., 2015; Zhang et al., 2017). However, the data on the content of nano- and microparticles of coal dust in the air of cities is insufficient. It is commonly known that particles with aerodynamic diameter of less than $200 \mathrm{~nm}$ settle at low speed (in $\mathrm{mm}$ or $\mathrm{cm}$ per hour), and particles less than $100 \mathrm{~nm}$ practically do not obey the law of gravity remaining suspended for a long time (Christian et al., 2008; Kumar et al., 2010).

The circulation of suspended particles of coal dust on the territory of enterprises and in the adjacent coastal sea water area leads to their accumulation and redistribution in the "air-human -biota-sea" system, where the air migration plays a leading role (Johnson and Bustin, 2006). The content of toxic elements in the rocks of coal-bearing strata largely determines the nature and the level of pollution of atmospheric air and water area adjacent to the transport terminals. The 
most common pollutants of coals are water-soluble compounds of heavy metals, including nickel, cobalt, lead, copper, arsenic, vanadium, manganese, chromium, beryllium, molybdenum, bismuth, zinc, niobium, lithium, and fluorine (Tang et. al., 2017; Kurilenko, 2019). In earlier study, a significant content of coal dust particles was found in seawater samples from Nakhodka Bay, ranging from $7 \%$ to $53 \%$ depending on the distance from the coal terminal (Lebedev et al., 2017). The research of Pacific Oceanology Institute of the Far Eastern Branch RAS revealed that the content of petroleum products and heavy metals in the marine area of Nakhodka Bay exceeded the threshold limit values (Naumov, 2016).

Water contamination by coal cause mortality and growth inhibition of marine organisms (Gibson, 2005; Berry et al., 2016; Berry et al., 2017). A disturbance in early embryogenesis and growth inhibition of embryos and larvae were observed in all samples of developing embryos of marine mussels in Nakhodka Bay under the influence of coal-dust particles (Naumov and Naidenko, 1997). Given the continuous increase of anthropogenic pressure on the environment, practical steps are needed to timely solve the problems of pollution of the atmosphere, hydrosphere, and pedosphere by nano- and microparticles (Golokhvast et al., 2017; Honarvar and Sami, 2019; Pikula et al., 2020a).

The aim of this work is a comprehensive study of the quantitative and qualitative composition of coal dust microparticles in Nakhodka city, and assessment of the environmental impact of coal dust microparticles on representatives of marine biota. In this study, we evaluated the toxicological effects of coal dust particles on representatives of marine aquatic organisms, namely the hemocytes of marine mollusks Modiolus modiolus.

\section{MATERIALS AND METHODS}

The samples of lignite coal (grade 1B) were collected at the Novoshakhtinsk open pit mine (seam IV PK64) located in Primorsky Krai, Mikhailovsky district, Novoshakhtinsky settlement. This lignite coal is used at energy enterprises of the Primorsky Krai during the heating season and it is exported to the Asia-Pacific region countries.

Morphological analysis of coal dust particles was performed using the Malvern Morphologi G3-ID equipment (Malvern Instruments Ltd., UK). The unit features sample dispergation system and automated static imaging with chemical identification of individual particles using morphologically directed Raman spectroscopy at the resolution of $4 \mathrm{~cm}^{-1}$. The analysis was performed using the diode laser with a wavelength of $785 \mathrm{~nm}$ and the resulting laser power of $4 \mathrm{~mW}$ in the low power mode. The use of micro-Raman spectroscopy made it possible to determine the size and basic chemical composition of each individual particle in samples (Kholodov, Golokhvast, 2016). Additionally, we analyzed the particle size distribution of coal in solution with the CytoFLEX flow cytometer (Beckman Coulter, USA): in the submicron range with direct light scattering of the violet laser $(405 \mathrm{~nm})$, and in the micron range with light scattering of the blue laser $(488 \mathrm{~nm})$. The cytometer was pre-calibrated with sets of particles in the ranges of $0.1-1 \mu \mathrm{m}$ and $1-50 \mu \mathrm{m}$ (Molecular Probes, USA).

We collected marine mollusks M. modiolus for the experiment in the Fedorov Bay (Vladivostok). The hemocytes of molluscs were isolated using a standard technique and incubated in 96-well plates with the addition of coal suspension. The suspension prepared by diluting a coal sample in artificial seawater was added to the mollusk hemocytes to obtain the concentrations of coal particles of $1,10,100$, and $1000 \mathrm{mg} / \mathrm{L}$. The control group consisted of cells in sea water without the coal particles. The experiment was repeated three times for each concentration and for the control group. All measurements were carried out after 2, 4, and 6 hours from the start of mollusk hemocytes incubation with the coal suspension.

We measured the changes in the state of cells exposed to the coal particles by the CytoFLEX flow cytometer (Beckman Coulter, USA) using fluorescent dyes. We recorded the change in the viability and integrity of cell walls, the change in the enzyme activity, and the changes in cell membrane polarization of $M$. modiolus hemocytes. The blue laser of the flow cytometer with a wavelength of $488 \mathrm{~nm}$ was used as a source of fluorescence excitation with all dyes. Cell size was determined by measuring the intensity of the forward scatter of blue laser ( $488 \mathrm{~nm})$. 
Table 1. Bioassay conditions measured by flow cytometry.

\begin{tabular}{lll}
\hline Endpoint & Fluorescent Dye & Cytometer Emission Filter \\
\hline Viability & Propidium iodide (PI) & ECD, $610 \mathrm{~nm}$ \\
Esterase activity & Fluorescein diacetate (FDA) & FITC, $525 \mathrm{~nm}$ \\
Membrane potential & $3,3^{\prime}$-dihexyloxacarbocyanine iodide $\left(\right.$ DIOC $\left._{6}\right)$ & FITC, $525 \mathrm{~nm}$ \\
\hline
\end{tabular}

The used fluorescent dyes and measured parameters are shown in Table 1. The features of using this set of biomarkers for determining the aquatic toxicity of particulate matter on marine organisms were described in our previous works (Pikula et al., 2019; Pikula et al., 2020b).

The morphological changes in the cells were monitored by the Axio Observer A1 optical microscope (Carl Zeiss, Germany).

\section{RESULTS AND DISCUSSION}

The particle size distribution of coal used in the study was represented by a fine fraction, most susceptible to dusting under the influence of external factors. Altogether, 300 thousand particles from the coal sample were examined by micro-Raman spectroscopy and 1 million particles by flow cytometry. Particles, in general, have oval elongated and broken shapes. The diameter of majority of particles ranges from $150 \mathrm{~nm}$ to $10 \mu \mathrm{m}$. As shown in Figure 1a, b, the predominant amount of coal particles is in the diameter range of about $300 \mathrm{~nm}$. In the micrometer range, the predominant diameter is $1-2 \mu \mathrm{m}$ (Figure 1a, c).

It should be noted that the analyzed coal samples taken from the coal seam are represented by a finer size fraction than coal, which was transported, stored, and then sampled directly at the territory of the coal terminal (Kirichenko et al., 2019).

a
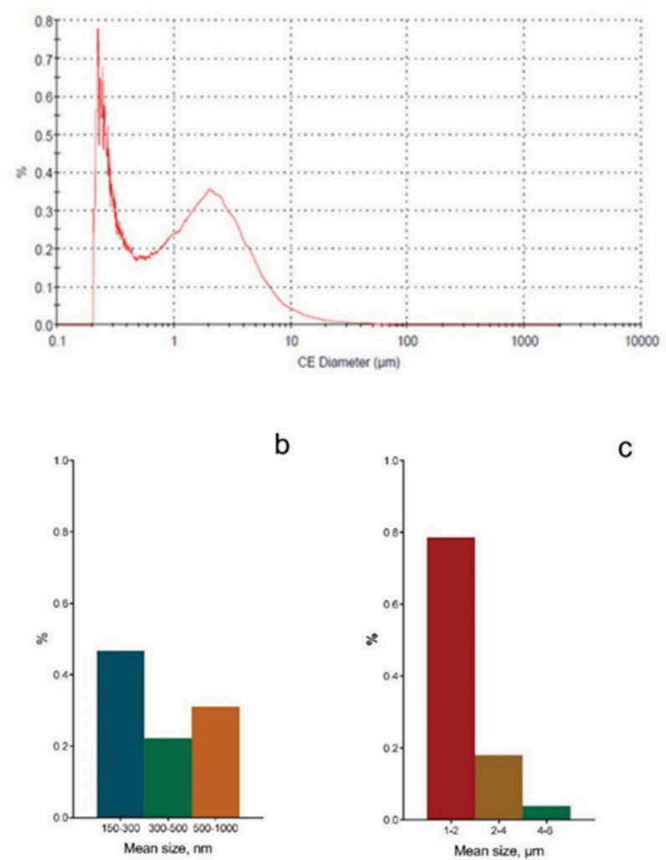

b

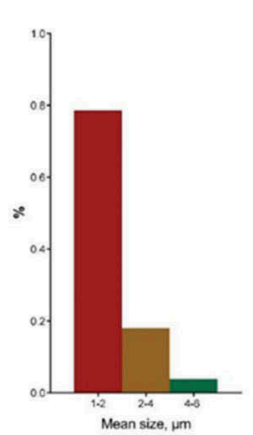

Figure 1. Particle size composition of the coal sample. a) micro-Raman spectroscopy data; b) and c) flow cytometry data. 
The results of the exposure of the mollusk M. modiolus hemocytes to the coal suspension are presented in Figure 2.

The viability was assessed by the absence of DNA cells staining with PI dye (Ostrander, 2005) registered by the absence of changes in the level of cell fluorescence in the ECD emission channel (Table 1). Dead cells were excluded from the count. According to the results of the tests, we can conclude that the investigated coal sample did not have a significant effect on the viability of the mollusk M. modiolus hemocytes. The proportion of alive cells in each measurement series after 2, 4, and 6 hours of exposure to the highest concentration of coal suspension $(1000 \mathrm{mg} / \mathrm{L})$ was almost at the same level as the proportion of alive cells in the control group for each series (Figure 1a). The greatest fluctuation and spread of values in different series of measurements was observed for the concentration of coal suspension of $100 \mathrm{mg} / \mathrm{L}$.

The change in the hemocyte esterase activity level after exposure to coal suspension was recorded as the fluorescence intensity of fluorescein formed due to the cleavage of FDA dye with cell esterases (Figure 2b). This index makes it possible to assess the enzyme activity and, therefore, the level of cell metabolism (Fontvieille et al., 1992). We can note that the cell metabolism activity increased slightly when exposed to coal suspension at concentrations of 1 and $10 \mathrm{mg} / \mathrm{L}$, while concentrations of 100 and $1000 \mathrm{mg} / \mathrm{L}$ caused the inhibition of cell metabolism. The increase in the time of exposure to coal suspension from 2 to 6 hours did not cause any further decrease in the cell metabolism level, since each series of measurements $(2,4$, and 6 hours) had a similar exposure level.

Maintaining the polarization level of cell membranes is an important indicator characterizing the ability of cells to perform barrier and metabolic functions that ensure cell activity.

a
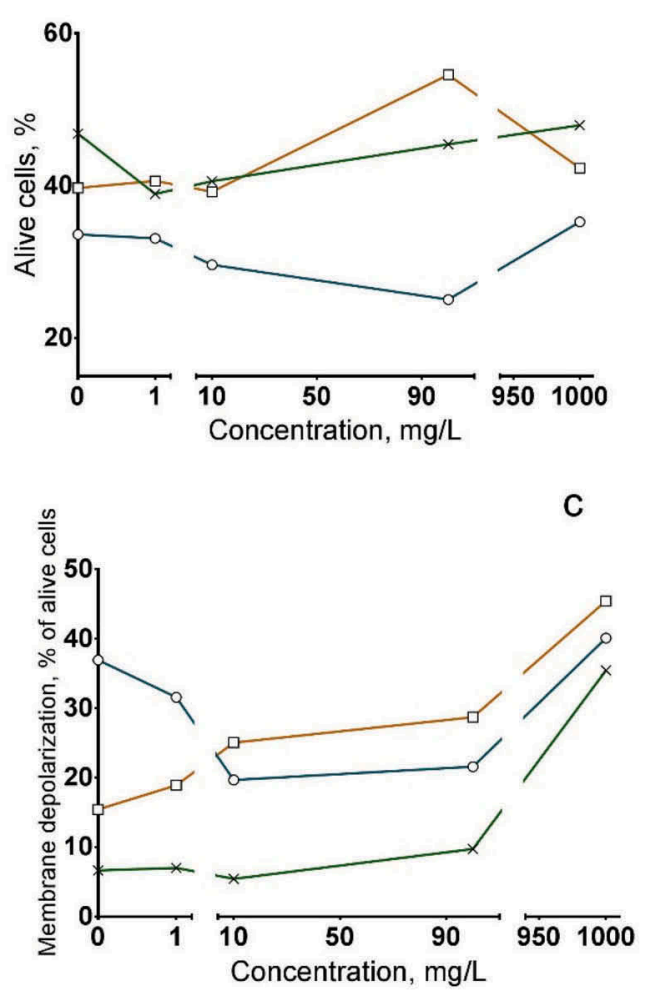
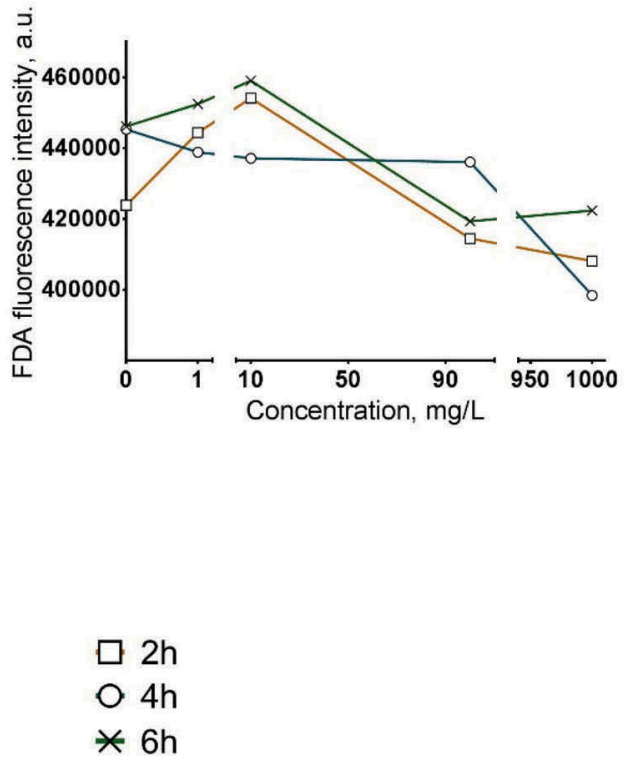

Figure 2. The change in the state of hemocytes of mollusk M. modiolus after 2, 4, and 6 hours of exposure to coal suspension at concentrations of $1,10,100$, and $1000 \mathrm{mg} / \mathrm{L}$. a) percentage of alive cells, b) change in esterase activity of cells, c) change in polarization of cell membranes; a.u. - arbitrary units. 

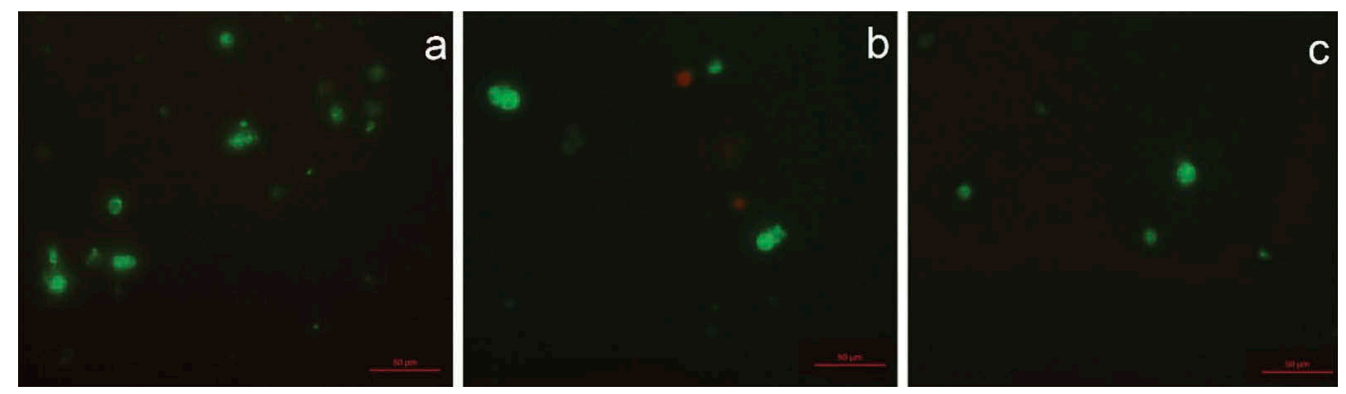

Figure 3. The hemocytes of mollusk M. modiolus after 6 hours of exposure. a) control group, b) $100 \mathrm{mg} / \mathrm{L}$, c) $1000 \mathrm{mg} / \mathrm{L}$.

Negatively charged cell membranes bind to the positively charged $\mathrm{DiOC}_{6}$ dye (Sabnis et al., 1997). When cell membrane functions are impaired, their charge decreases and, accordingly, the bound $\mathrm{DiOC}_{6}$ dye is released into the medium (Grégori et al., 2003). As a result of the mollusk M. modiolus exposure to the coal suspension, no significant effects were observed at coal suspension concentrations up to $100 \mathrm{mg} / \mathrm{L}$. (Figure 2c). At the coal suspension concentration of $1000 \mathrm{mg} / \mathrm{L}$, membrane depolarization of about $20 \%$ of alive cells of hemocytes was observed. A change in the fluorescence level of cell membranes is shown in Figure 3.

It should be noted that the change in polarization of cell membranes during the exposure for 2, 4, and 6 hours has a common trend, which indicates the absence of an increase in the negative effect over time in the measurement range.

\section{CONCLUSIONS}

We did not detect acute toxicological hazard of coal dust particles to the representatives of marine biota even at extremely high concentrations. There is a decrease in the enzyme activity and partial depolarization of membranes (an average of 20\%) exposed to coal particles. The observed changes in the state of hemocytes of mollusk $M$. modiolus suggest that there is a chronic exposure. Further long-term toxicological studies are needed to identify the effects of coal dust on marine aquatic organisms.

This study will be continued using the environmental monitoring system which is planned to be set up at various locations in Nakhodka city.

\section{ACKNOWLEDGEMENTS}

The study was funded by RFBR, project number 19-05-50010, and by the grant from the President of the Russian Federation for young candidates of sciences (PhD) MK-2461.2019.5.

\section{REFERENCES}

Berry, K., Hoogenboom, M., Flores, F., Negri, A.P. 2016. Simulated coal spill causes mortality and growth inhibition in tropical marine organisms. Scientific Reports 6: 25894. doi:10.1038/srep25894.

Berry, K. L., Hoogenboom, M. O., Brinkman, D. L., Burns, K. A., Negri, A. P. 2017. Effects of coal contamination on early life history processes of a reef-building coral, Acropora tenuis. Marine pollution bulletin 114(1): 505-514. doi:10.1016/j.marpolbul.2016.10.011.

Christian, P., Von der Kammer, F., Baalousha, M., Hofmann, Th. 2008. Nanoparticles: structure, properties, preparation and behaviour in environmental media. Ecotoxicology 17: 326-343. https://doi.org/ 10.1007/s10646-008-0213-1.

Fontvieille, D.A., Outaguerouine, A., Thevenot, D.R., 1992. Fluorescein diacetate hydrolysis as a measure of microbial activity in aquatic systems- Application to activated sludges. Environmental Technoogy 13(6): 531-540. doi: 10.1080/09593339209385181. 
Gibson, R., Atkinson, R., Gordon, J. (ed.). 2005. Oceanography and Marine Biology. Boca Raton: CRC Press. doi:10.1201/9781420037449.

Golokhvast, K.S., Kupriyanov, A.N., Manakov, Yu.A., Agoshkov, A.I., 2017. Environmental characteristic of air suspensions at coal production objects: From extraction to combustion. Gornyi Zhurnal 4: 87-90. doi:10.17580/gzh.2017.04.18 (In Russian).

Grégori, G., Denis, M., Lefèvre, D., Beker, B., 2003. A flow cytometric approach to assess phytoplankton respiration. Advanced Flow Cytometry: Applications in Biological Research. Springer Netherlands, Dordrecht: 99-106. doi:10.1007/978-94-017-0623-0_15

Honarvar, A.R., Sami, A. 2019. Towards sustainable smart city by particulate matter prediction using urban big data, excluding expensive air pollution infrastructures. Big data research 17: 56-65. doi:10.1016/j.bdr.2018.05.006.

Johnson, R., Bustin, R.M. 2006. Coal dust dispersal around a marine coal terminal (1977-1999), British Columbia: The fate of coal dust in the marine environment. International Journal of Coal Geology 68 (1-2): 57-69. doi:10.1016/j.coal.2005.10.003.

Kholodov, A.S., Golokhvast, K.S. 2016. Complex research of the particles which cause air pollution by laser granulometry, Raman-spectrometry and IR-spectrometry. Proc. SPIE 10176: 101760N1-101760N-6, doi:10.1117/12.2268229.

Kirichenko, K.Yu., Kholodov, A.S., Vakhniuk, I.A., Gusev, D.S., Kiryanov, A.V., Drozd, V.A., Golokhvast, K.S., 2019. Research of air pollution with fine coal dust (Nakhodka, Primorsky krai). Bulletin of Kamchatka State Technical University 50: 6-13. doi:10.17217/2079-0333-2019-50-6-13 (In Rusian).

Kumar, P., Fennell, P., Robins, A. 2010. Comparison of the behaviour of manufactured and other airborne nanoparticles and the consequences for prioritising research and regulation activities. Journal of Nanoparticle Research 12: 1523-1530. doi:10.1007/s11051-010-9893-6.

Kurilenko, V.V. 2019. Fundamentals of environmental geochemistry. V.V. Kurilenko (ed.), Ecological Problems Geology: Proceedings of XIX International Youth Scientific Conference-school; SaintPetersburg, 2-7 June 2019. Saint-Petersburg: Saint-Petersburg State University (In Russian).

Lebedev, A.A., Tikhonova, O.A., Blinovskaya, Ya.Yu., Chaika, V.V., Kirianov, A.V., Khristophorova, N.K., Pikula, K.S., Shevchenko, V.P., Golokhvast, K.S. 2017. Coal terminal impact on marine suspention composition: Nakhodka Gulf (Japan Sea). Proceedings of the Russian State Hydrometeorological University 48: 195-201 (In Russian).

Lelieveld, J., Evans, J. S., Fnais, M., Giannadaki, D., Pozzer, A. 2015. The contribution of outdoor air pollution sources to premature mortality on a global scale. Nature 525: 367-371. doi:10.1038/ nature15371.

Naumov, Yu.A., Naidenko, T.Kh. 1997. The ecological state of Nakhodka Bay. Izvestiâ Tihookeanskogo naučno-issledovatel'skogo rybohozâjstvennogo centra 122: 524-537 (In Russian).

Naumov, Yu.A. 2016. Sea ports and their water areas state of the environment (through the example of Nakhodka Bay port complex on the Sea of Japan). International journal of applied and fundamental research 10(4): 623-626. (In Russian).

Ostrander, G.K. (ed.) 2005. Techniques in aquatic toxicology. Boca Raton: CRC Press.

Pikula, K.S., Chernyshev, V.V., Zakharenko, A.M., Chaika, V.V., Waissi, G., Hai, L.H., Hien, T.T., Tsatsakis, A.M., Golokhvast, K.S. 2019. Toxicity assessment of particulate matter emitted from different types of vehicles on marine microalgae. Environmental research 179: 108785. doi:10.1016/j. envres.2019.108785.

Pikula, K.S., Zakharenko, A.M., Chaika, V.V., Kirichenko, K.Y., Tsatsakis, A.M., Golokhvast, K.S. 2020a. Risk assessment in nanotoxicology: Bioinformatics and computational approaches. Current Opinion in Toxicology 19: 1-6. doi:10.1016/j.cotox.2019.08.006.

Pikula, K., Chaika, V., Zakharenko, A., Markina, Z., Vedyagin, A., Kuznetsov, V., Gusev, A, Park, S, Golokhvast, K. 2020b. Comparison of the level and mechanisms of toxicity of carbon nanotubes, carbon nanofibers, and silicon nanotubes in bioassay with four marine microalgae. Nanomaterials 10 (3): 485. doi:10.3390/nano10030485.

Sabnis, R.W., Deligeorgiev, T.G., Jachak, M.N., Dalvi, T.S., 1997. DiOC(6)(3): a useful dye for staining the endoplasmic reticulum. Biotech. Histochem. 72(5),253-258. doi:10.3109/10520299709082249.

Tang, Z., Chai, M., Cheng, J., Jin, J., Yang, Y., Nie, Z., Huang, Q., Li, Y. 2017. Contamination and health risks of heavy metals in street dust from a coal-mining city in eastern China. Ecotoxicology and Environmental Safety 138: 83-91. doi:10.1016/j.ecoenv.2016.11.003.

Zhang, Q., Jiang, X., Tong, D.,Davis, S.J., Zhao, H., Geng, G., Feng, T., Zheng, B., Lu, Z., Streets, D. J., Ni, R., Brauer, M., Donkelaar, A., Martin, R.V., Huo, H., Liu, Z., Pan, D., Kan, H., Yan, Y., Lin, J., He, K., Guan, D. 2017. Transboundary health impacts of transported global air pollution and international trade. Nature 543: 705-709. doi:10.1038/nature21712. 